\title{
NECROLÓGICA. MÍKEL DE EPALZA FERRER (1938-2008)
}

\author{
Luis F. Bernabé Pons
}

El profesor Míkel de Epalza murió el 6 de diciembre de 2008, meses después de un desgraciado accidente. Aunque avisados durante este período de su estado de salud, extremadamente delicado, la sacudida no fue menos para quienes estábamos cerca de él. Recién jubilado en febrero de ese mismo año, había entrado en su nuevo estado ilusionado por poder dedicar más tiempo a leer y a reflexionar, a investigar y a escribir, sin sospechar que sólo iba a poder disfrutar de esa ilusión durante cuatro meses. Esperaba de forma especial la llegada de 2009, aniversario de la expulsión de los moriscos valencianos, ante el conjunto de actividades programadas, para poder disfrutar del intercambio de pareceres en lo que había sido una de sus dedicaciones científicas favoritas. Pero ya no pudo ser.

Míkel de Epalza había nacido en Pau (Francia), el 18 de febrero de 1938, en el seno de una conocida familia vasca que se encontraba exiliada en Francia desde unos meses antes de la caída de Bilbao en manos de las tropas rebeldes. En Francia vivió con sus padres y sus tres hermanos, así como con otros miembros de la familia, durante diez años. Vueltos a Bilbao en 1948, al poco tiempo su padre, Tomás de Epalza, ingeniero forestal, fue destinado a las Islas Baleares y la familia se trasladó a Palma de Mallorca, donde Míkel de Epalza completó su bachillerato.

Tras ingresar en el noviciado de la Compañía de Jesús en Tortosa, comenzó con los jesuitas sus estudios de Filosofía Eclesiástica, que acabaría en la sede de la Universidad Gregoriana en Sant Cugat del Vallès (1961), y más tarde el título de Filosofía en la Universidad de Barcelona en 1963. En Sant Cugat del Vallés entraría por primera vez en contacto con los Estudios Árabes e Islámicos a través de su lectura de la Islamología de Félix M. Pareja -a quien conocería más adelante en Madrid-, estudiando el fenómeno de las peregrinaciones como hecho religioso. Ese encuentro con lo árabe y lo islámico, marcado por Pareja, en la Facultad jesuítica dependiente de la Universidad Gregoriana de Roma, y en el ambiente marcado por la esperanza de los años sesenta y del Concilio Vaticano II, y la cada vez mayor presencia del aperturismo irreligioso, serán fundamentales en su forma de entender el mundo del diálogo islamo-cristiano. Como desarrollo lógico de esos primeros estudios universitarios y de esa curiosidad que 
se le había despertado, estudió Filología Semítica en la Universidad de Barcelona, desempeñando, durante el último año de sus estudios allí, labores de profesor ayudante. Se licenció, con Premio Extraordinario, en 1965.

También en el último año de su licenciatura en Filología Semítica se topó con la figura a la que habría de consagrar su tesis doctoral: Anselm o En Telm Turmeda, fraile franciscano convertido al islam en Túnez hacia 1385, tomando el nombre de 'Abd Allâh al-Tarŷumân, y escritor bien conocido de las letras catalanas medievales. Epalza dedicaría su tesis a la obra en árabe que haría de Turmeda un escritor muy conocido también en el Mediterráneo musulmán: la Tuhfat al-Arîb, un prolijo tratado de polémica anticristiana. El tema, que le fue sugerido por Martí de Riquer y que desarrollaría con la dirección de Juan Vernet, empujó a Epalza a un largo viaje por el Mediterráneo, de Occidente a Oriente, a la busca de manuscritos de la obra polémica del escritor musulmán mallorquín. Este largo viaje científico, que tuvo asimismo mucho de iniciático (sólo conocía Túnez, de un viaje anterior en 1962), le posibilitó el convertirse en el gran especialista en la obra religiosa islámica del funcionario y traductor hispanotunecino. La tesis sobre Turmeda, que fue defendida en 1967, obtuvo el Premio Ciutat de Barcelona de Investigación Literaria y tuvo el raro privilegio de ser editada en castellano por la prestigiosa Academia Nazionale dei Lincei (1971). De esta forma, al francés y al castellano de su infancia se sumaron el catalán y el árabe como las cuatro lenguas que más usó en su vida.

La lectura de la tesis doctoral fue un jalón muy importante en su vida de estudiante, pero no detuvo lo que denominó su media vida de trashumancia, que fechaba entre 1954 y 1979. En 1968 se marchó a la Universidad de Lyon, en donde enseñó español y cultura hispana mientras se licenciaba en Teología Católica (Lyon-Fourvière, 1970) y se diplomaba en enseñanza del árabe audiovisual (Beirut-París, 1969). En 1971 se marchó contratado a la Universidad de Túnez (1971-1973), país en el que se convirtió en un gran revulsivo para la activación de la cultura española en Túnez y en el que inició sobre el terreno una de las líneas de investigación a la que consagraría más tiempo y esfuerzos: los moriscos emigrados a la Regencia Otomana después de la expulsión de 16091614, a los que se había acercado ya en su tesis. Durante el curso 1973-1974 fue profesor en Argelia, simultaneando docencia en las universidades de Argel y de Orán. Ya de vuelta a España, fue profesor en la Universidad Pontificia de Madrid-Comillas (1974-1975) y en la Autónoma de Madrid. En 1979 ganó la plaza de profesor adjunto en la recién creada Universidad de Alicante, de la que fue catedrático diez años más tarde. En Alicante dio por finalizada esa etapa trashumante de su vida, estableciéndose allí de forma definitiva. En la Playa de San Juan, donde fijó su residencia durante años, contrajo matrimonio en 1981 con María Jesús Rubiera Mata, también catedrática de Estudios Árabes, quien trasladó su residencia y su trabajo asimismo a la ciudad de Alicante. En la Universidad de Alicante centró la mayor parte de su trabajo académico y científico, aunque sin olvidar sus numerosos lazos nacionales e internacionales. Allí se empeñó en crear, junto a María Jesús Rubiera, Margarita La Chica y otros pocos 
profesores, un núcleo de docencia, investigaciones y publicaciones que contribuyesen a ir formando un grupo que se consolidase con el tiempo. A base de mucho esfuerzo y perseverancia se fueron consiguiendo logros académicos (Primer Ciclo, Doctorado, Licenciatura completa...) propiciados en buena parte por la intensa labor investigadora llevada a cabo: la cátedra obtenida por Míkel de Epalza pertenecía de hecho al programa PROPIO, destinado a apoyar a las mejores trayectorias investigadoras. En su jubilación en febrero de 2008, el Área de Estudios Árabes e Islámicos de la Universidad de Alicante contaba con catorce profesores y se aprestaba a adaptarse a los nuevos tiempos de la educación superior.

Casi treinta años de docencia en la Universidad de Alicante hicieron de Míkel de Epalza un profesor conocido y reconocido en el campus de San Vicente del Raspeig. Sus dotes innatas para la comunicación se afilaban en la muela del interés en que sus alumnos captasen lo esencial de sus clases y, especialmente, sus hipótesis más atractivas. Puesto que para él la investigación y la docencia no eran compartimentos estancos, trasladaba sus dudas, sus reflexiones y sus hallazgos a sus alumnos, a la vez que con ellos destilaba la forma de comunicar eficazmente sus propuestas. Famosa se hizo en los años ochenta su forma de enseñar geografía del Magreb, poniendo el mapa del Mediterráneo cabeza abajo. Cuando el 17 de enero de 2008 Míkel de Epalza dio su última clase reglada en el Salón de Grados de la Facultad de Filosofía y Letras, éste rebosaba de compañeros y amigos, pero sobre todo de antiguos alumnos. Su interés docente le llevó asimismo a trascender los límites de la Universidad, acudiendo a impartir conferencias de carácter divulgativo en toda la provincia, en actividades de extensión universitaria que llevaron su gran y atrayente humanidad a Aulas de la Tercera Edad, Asociaciones de Fiestas, Grupos Culturales, Museos $\mathrm{y}$ todas aquellas instituciones que vertebran las manifestaciones culturales en la provincia. A todos ellos acudía con interés mostrando algún aspecto de su ciencia en los Estudios Árabes e Islámicos conectado generalmente con el lugar al que acudía. Habiendo entendido a la perfección lo que significaba la descentralización universitaria, Epalza dedicó mucho interés al estudio de lo árabe en Alicante, en historia, onomástica, toponimia, urbanismo..., incluso en sus manifestaciones en las fiestas de Moros y Cristianos, que tanto le llamaron la atención por su carácter morófilo festivo. Al tiempo, procuraba enseñar lo que él mismo había aprendido e investigado, respetando y animando los estudios locales como plataforma en la que estudiar los planos generales de determinados temas. Esa última clase en la Universidad precisamente tuvo por tema "Alicante y el Alacantí árabes. Espacios y toponimia (siglos VIII-XIII)", aunando de forma simbólica varios de los campos de su interés científico con el estudio y aprecio con la tierra que le había acogido.

Los intereses científicos de Míkel de Epalza abarcaban muchos espacios y tiempos dentro de los estudios árabes e islámicos. Lector infatigable, su capacidad de trabajo no conocía descanso, como podía comprobarse cada lunes en el Departamento, cuando volvía del fin de semana cargado de comentarios, 
sugerencias y tareas para todo el mundo a su alrededor. De esto podemos dar fe sus compañeros en Alicante, pero también las muchas personas de España y del extranjero que recibían de continuo cartas suyas con notas, fotocopias, fotografías, propuestas o simples comentarios. Porque una de las características más acusadas del Epalza académico era su increíble número de amistades y contactos alrededor del mundo, cultivado desde muchos años atrás. Partidario declarado de la colaboración científica -como muestran sus varios trabajos escritos en coautoría-, Míkel de Epalza había creado unas redes personales que en varias ocasiones cristalizaron en redes de grupos científicos (como la establecida con el grupo investigador de Robert I. Burns, de UCLA, o el de JeanLouis Miège, de la Universidad de Provence), pero que siempre le sirvieron para mantenerse en contacto con el mundo académico nacional e internacional en años en los que no era usual mantener relaciones científicas foráneas. Los contactos personales fueron siempre para Epalza una forma de estímulo intelectual. Así vio siempre, por ejemplo, su relación temprana con dos personas que fueron importantes en este sentido en su vida: el embajador Alfonso de la Serna, para sus estudios sobre los moriscos en Túnez, y el arabista y archivero Guillermo Guastavino, para su interés por Argelia. Esta red de contactos, amistades y colaboraciones tenía también otra característica cercana al concepto científico de Epalza: su notable multidisciplinariedad. Frente a devotos de famas y credenciales, él creía en el trabajo. Y en el trabajo apoyado en las aportaciones de varias ramas del conocimiento. Un simple vistazo a sus publicaciones muestra que la interdisciplinariedad fue para él una realidad desde el principio, cuando tal concepto no se estilaba por estos pagos.

El mundo de la religión fue, lógicamente, uno de sus primeros intereses científicos, que nunca abandonaría a lo largo de su vida. Un primer interés por la fenomenología de la religión y la psicología evolutiva de la vivencia religiosa dio pronto paso a su estudio del islam como gran religión monoteísta y como creencia relacionada, teológica y socialmente, con el cristianismo. Un primer acercamiento al hecho espiritual de la peregrinación y a la caracterización del Profeta Muhámmad se combinó en aquellos años sesenta con el ambiente propiciado por el Concilio Vaticano II y en especial con la declaración Nostra Aetate sobre las relaciones de la Iglesia con las religiones no cristianas, así como la influencia renovadora de pensadores como el jesuita Pierre Teilhard de Chardin. Este contexto es esencial para comprender tanto el primer acercamiento de Epalza al hecho religioso musulmán, como su visión de las relaciones islamo-cristianas. Con su continuado aserto de que en religión comparada las categorías bueno y malo habían de ser desterradas, Epalza se esforzó primero en tender puentes para el entendimiento entre creyentes de ambas religiones y, segundo, en explicar a los españoles las realidades del islam alejando su explicación de prejuicios tradicionales. De aquí surgió una forma "positiva" de ver al islam y a su Profeta que se convirtió en protagonista de los Congresos Islamo-Cristianos de Córdoba en 1974, 1977 y 1979. Especialmente llamativo fue el II Congreso, en el que dicho espíritu se materializó en el discurso 
-que fue medido hasta el extremo- del cardenal Vicente Enrique y Tarancón: "Aprecio positivo de Jesús y de Mahoma en el Cristianismo y en el Islam". Fue ésta una postura que le granjeó la simpatía de muchos hombres de religión, musulmanes y cristianos. También la confusión -sea todo dicho- de muchos que alegremente le adjudicaron (scripta manent) una conversión al islam. Ciertas desilusiones y una propia evolución, unidas a su desvinculación de los jesuitas, le hicieron alejarse de la primera línea del diálogo islamo-cristiano, aunque durante toda su vida siguió muy de cerca su evolución, a través de su relación con la revista Islamochristiana, de los Padres Blancos, y sus contactos con religiosos comprometidos en ese terreno. Lo que nunca abandonaría fue esa capacidad de acercarse al islam desde una óptica no confesional, intentando comprenderlo en sus propias explicaciones para después transmitir sus propias reflexiones. Toda su obra islamológica se tiñe de esa visión, irreligiosa en sí, de positividad y de acercamiento a la vivencia religiosa del otro: desde sus explicaciones acerca de los nombres de Dios hasta su particular forma de concebir la traducción del Corán, pasando por la figura de Jesús contemplada por las tres religiones o por la caracterización de lo permanente en el islam.

Junto con el análisis del islam, fue la Historia otro de los grandes vectores de las ocupaciones científicas de Epalza. La Historia referida a los árabes y al islam en sus distintas manifestaciones en todas las orillas del Mediterráneo. Estudioso de las relaciones entre los países del Magreb y de Europa desde la Edad Media a nuestros días, su curiosidad le llevó a explorar terrenos poco transitados por los especialistas de las relaciones euroárabes como los tratados de paz, la cartografía o los estudios árabes sobre España. En esa Historia mediterránea, en la que se insertó en primera instancia siguiendo las huellas de la vida y la polémica religiosa de Anselm Turmeda, Míkel de Epalza encontró algunos reflejos de su propia existencia en los exilios, la trashumancia, las polémicas en nombre de la religión o el acogimiento de los exiliados. Un buen ejemplo de ello es uno de sus temas fundamentales, los moriscos, comunidad hispánica expulsada a la que se había aproximado en su tesis doctoral pero que en Túnez conocerá de forma más detenida a través de la lectura y del contacto con Slimane-Mustafa Zbiss, director del Centre d'Etudes Andalouses y epicentro del estudio de la huella morisca en Túnez en los años setenta. Aunque Epalza ya había transitado el mundo intelectual de los moriscos a través de la posible autoría de un texto fascinante, el Evangelio de Bernabé, fue a su llegada a Túnez cuando comenzó a estudiar de forma sistemática a los moriscos emigrados, analizando los archivos del consulado francés, sistematizando sus huellas onomásticas, toponímicas, literarias y culturales en general e introduciendo a algunos estudiosos tunecinos (M. Boughanmi y especialmente Abdel-Hakim Gafsi Slama) en el estudio científico de los moriscos y sus descendientes en Túnez. Epalza estudió a los moriscos primero en su extrañamiento en el XVII y en su descendencia en el XVIII y XIX, con los textos del trinitario Francisco Ximénez, y más tarde, en un viaje cronológico hacia atrás, en su presencia en la España del XVI. Le impresionó especialmente en Túnez tanto la ordenada acogi- 
da que las autoridades políticas y religiosas dieron a los moriscos como la conciencia positiva de los tunecinos acerca del elemento morisco en su pasado nacional. En Túnez actuó como catalizador de diversas iniciativas a favor del estudio científico de los moriscos: dos libros colectivos sobre los moriscos en Túnez, en 1973 y 1983, organizados por él junto con otros colaboradores, pusieron el punto de partida del interés moderno de los investigadores magrebíes por los moriscos. En Túnez, asimismo, Míkel de Epalza se convirtió en un personaje conocidísimo y casi imprescindible del ambiente intelectual de la época, hasta el punto de que aún hoy su figura allí sigue siendo enormemente popular (...y un día llegó a parar un avión en el aeropuerto de Túnez-Cartago...).

Estudiando a los moriscos como "los últimos musulmanes de la Península Ibérica", Epalza dio cuenta de su continuidad estructural con los mudéjares de la Edad Media en tanto comunidad islámica viviendo bajo poder cristiano. Con esta visión de continuidad espiritual enfocará su conocido manual sobre los moriscos, Los moriscos antes y después de la expulsión, tomando como eje cronológico el de su alejamiento forzoso de la tierra de sus antepasados, previo a unos nuevos asentamientos fuera de España. Aunque su labor científica se ocupó de otros muchos campos, los moriscos fueron una línea que le acompañó toda su vida, y que llegará a dar frutos póstumos. Fue sin duda uno de los grandes animadores intelectuales del estudio de los moriscos en España, organizador de dos congresos internacionales, director de trabajos académicos y fundador y director, junto con María Jesús Rubiera, de la única revista científica dedicada al tema, Sharq Al-Andalus, que tras una andadura dedicada a los estudios árabes en general, fue reorientada con la colaboración del Centro de Estudios Mudéjares de Teruel, en revista dedicada a los mudéjares y moriscos. Se hace inevitable señalar que en 2009, año del aniversario de la expulsión de los moriscos, su figura fue recordada y evocada en todos aquellos congresos reunidos para abordar el tema del que había sido gran especialista.

El estudio de la Historia árabe-islámica mediterránea y peninsular le llevó asimismo a campos en los que su conocimiento de las realidades musulmanas podía ser aplicado: como el urbanismo musulmán y sus diferentes manifestaciones institucionales, con un esbozo de "modelo operativo" que todavía sigue siendo usado con efectividad por investigadores del pasado físico árabe de las ciudades; o bien las estructuras, físicas y espirituales, de las mezquitas, o también el desarrollo y uso de los baños en las ciudades árabes del País Valenciano. Una mención especial merece su dedicación al campo de las rábitas en la Península. Organizador de encuentros interdisciplinares, coeditor con F. Franco Sánchez de dos magníficos libros de actas e inspirador y estudioso del fabuloso yacimiento arqueológico de Guardamar del Segura, puede con justicia afirmarse que hay un antes y un después de Míkel de Epalza en el estudio de las rábitas en España.

Este estudio de las realidades urbanas andalusíes iba a unirse con otro al que también se dedicó de forma intensa: el de la toponimia. Estudiada la toponimia no de forma aislada, desde un aspecto puramente lingüístico, sino insertada en su realidad física, histórica y social, Míkel de Epalza se ocupó en 
estudiar a partir de la toponimia los caminos interurbanos, las realidades extraurbanas así como las estructuraciones comarcales. Su aportación a la realidad toponímica catalana y a la alicantina (junto con María Jesús Rubiera), recogida la mayor parte en el boletín de la Societat d'Onomàstica, es muestra de un estudio que pretende estructurar la realidad vial y comarcal del territorio andalusí al tiempo que responder a ciertos interrogantes acerca de la presencia constante de ciertos topónimos: es el caso, por ejemplo, del Cid, término que en su vertiente toponímica u onomástica le acompañará desde antiguo.

Uno de los campos que más reflexiones y más satisfacciones le proporcionó en los últimos años de su carrera académica fue el traductológico. Míkel de Epalza había traducido numerosos textos del árabe para su propio trabajo científico, pero nunca había dedicado el grueso de su esfuerzo a la actividad traductora y a la reflexión traductológica. Y el caso es que él mismo confesó en algunas páginas que dos de sus primeros grandes modelos de acercamiento a las realidades islámicas habían sido dos traducciones del Corán: la de su profesor en Barcelona Juan Vernet y la de la islamóloga francesa Denise Masson, la "Dama de Marrakesh". Epalza siempre había admirado el esfuerzo de esta última -inspirado en Massignon- en conseguir un texto francés que respondiese lo más posible no sólo al contenido semántico del Corán, sino a toda la realidad lingüística que supone el texto coránico, y que pudiera ser apreciado por los propios árabes musulmanes bilingües. Apreciaba asimismo grandemente la traducción de un antiguo amigo suyo, el profesor Julio Cortés, de la que estimaba el afilado rigor traductológico combinado con un delicado gusto de su dicción castellana. Por motivos diversos, en especial la ausencia de traducción coránica a esa lengua, Epalza optó por realizar la traducción al catalán, formando un equipo con Josep Forcadell y Joan Perujo, de la Universidad de Alicante. Su traducción, en resumen, quería reproducir en lo posible la belleza formal de la prosa rimada coránica y asimismo recoger todos los sentidos que ciertos términos árabes reproducen y que se perderían con una traducción unívoca. Enmarcando su traducción, además, Epalza quería mostrar el pasado de esas traducciones del Corán en ámbito hispánico, la especial naturaleza árabe e islámica del texto coránico y los especiales principios que habían guiado al equipo en su labor. El resultado de todo ello fue L'Alcorà. Traducció de l'àrab al català, introducció a la lectura i cinc estudis alcorànics (Barcelona, 2001), Premio Nacional de Traducción en 2002. El libro fue considerado desde su aparición una de las grandes obras de Epalza y estimado por los expertos como un auténtico punto y aparte en la historia de las traducciones del Corán.

Quisiera referirme para finalizar a un campo de trabajo que Míkel de Epalza apreciaba grandemente, si bien muchas veces no ha solido tener la consideración que merece: el trabajo bibliográfico y de comunicación de la labor científica. Una apreciable parte de su tiempo lo dedicó, a solas o en colaboración, a recopilaciones bibliográficas, comentadas o sin comentar, a comentarios de diversos libros sobre un tema, presentaciones de congresos científicos 
o apreciaciones sobre líneas de investigación en curso. Con ello no sólo daba cuenta del ritmo de sus lecturas o del volumen de sus noticias, sino que ponía con generosidad a disposición de la comunidad científica tanto la recopilación de lo publicado sobre un tema como las novedades sobre el mismo. La publicación de monografías bibliográficas o su continua participación en destacadas revistas bibliográficas (Indice Histórico Español, Bulletin Critique des Annales Islamologiques, Aljamía) muestran la importancia que siempre dio a esta labor, ímproba en los tiempos pre-internet, reafirmado en su creencia de hacer circular la información entre la comunidad científica.

Hombre lleno de actividad y de ideas, conversador infatigable, defensor a ultranza del diálogo sin trabas con el mundo árabe-islámico, muchas son las huellas que Míkel de Epalza dejó entre sus compañeros y sus amigos. A la hora de su muerte recibimos en el Ârea de Estudios Árabes e Islámicos de la Universidad de Alicante mensajes de condolencia procedentes de cuatro continentes y de más de quince países. Como siempre a lo largo de su vida, estuvo muy acompañado.

\section{BIBLIOGRAFÍA}

«Sobre un posible autor español del Evangelio de Bernabé», Al-Andalus, XXVIII, 1963, pp. 479-491.

«L'auteur de La Tuhfat Al-Arīb, Anselm Turmeda ('Abdallāh Al-Tarjumān)», Ibla, 28, 1965, pp. 261-290.

«Nuevas aportaciones a la biografía de Fray Anselmo Turmeda (Abdallah Al-Tarchuman)», Analecta Sacra Tarraconensia, 38, 1965, pp. 87-158.

«Declaración sobre las relaciones de la iglesia con las religiones no-cristianas. Comentario», Vaticano II. Enciclopedia conciliar. Historia, doctrina, documentos, Barcelona, Regina, 1967, pp.307-318.

«Autour d'un centenaire: Le voyageur espagnol Domingo Badía (Ali Bey el Abbasí) en Túnez », Ibla, 31, 1968, pp. 51-61.

«Algunos juicios teólogicos de Asín Palacios sobre el Islam», Pensamiento. Revista de investigación e información filosófica, 25, 97-99, 1969, pp. 145-182 [reed. modificada en Bulletin of the faculty of arts. University of Cairo, 56, 1992, pp. 285-289].

«Massignon et Asín Palacios. Une longue amitié et deux approches différentes de l'Islam», L'Herme, 13, 1969, pp. 157-169.

«Moriscos y andalusíes en Túnez en el siglo XVII», Al-Andalus, 34, 1969, pp. 247327 [trad. francesa en Études sur les Moriscos andalous en Tunisie, pp. 150-173].

«Recherches récentes sur les émigrations des 'moriscos' en Tunisie», Les Cahiers de Tunisie, XVIII, 69-70, 1970, pp. 139-147 [Trad. esp. en Zbiss, Slimane Mostafa - Gafsi, Abdelhakim - Boughanmi, Mohieddine - Epalza, 
Míkel de, Etudes sur les Morisques Andalous, Túnez, Institut Nationale d'Archéologie et d'Art, 1983, pp. 91-94].

- La Tuhfa. autobiografía y polémica contra el Cristianismo de 'Abdallāh Al-Tarŷumān (Fray Anselmo Turmeda), Roma, Accademia Nazionale Dei Lincei, 1971. Nueva edición, con "Nueva presentación y prólogo" de María Jesús Rubiera y una "Puesta al día bibliográfica sobre Turmeda (1967-1992)" de Míkel de Epalza, Madrid, Hiperión, 1994.

«España y su Historia vista por los árabes actuales (a partir de los textos de Enseñanza Media de Siria)», Almenara, 2, 1972, pp. 52-108.

«Lepanto, visto desde tierras de 'turcos'», Almenara, 2, 1972, pp. 215-220. «Una misión etnológica sobre los moriscos refugiados en Túnez», Hispanic Review, 40, 1972, pp. 484-485.

«Notes pour une histoire des polémiques anti-chrétiennes dans l'Occident Musulman», Arabica, 18, 1973, pp. 99-106.

Islam. Christianisme et Incroyance. A la recherche d'un langage et d'une entente, Túnez, Maison Tunisienne de l'édition, 1973, 1979.

Études sur les Moriscos andalous en Tunisie, Madrid, Dirección General de Relaciones Culturales \& Instituto Hispano-Árabe de Cultura, 1973. (Ed., con Ramón Petit.)

«Moriscos et Andalous en Tunisie Au XVIIe Siècle», en Etudes sur les Moriscos andalous en Tunisie, pp. 150-186.

«Algunas consecuencias del Tratado de Paz Hispano-Argelino de 1786», Homenaje a Guillermo Guastavino. Miscelánea de Estudios en el año de su jubilación como Director de la Biblioteca Nacional, Madrid, Asociación Nacional de Bibliotecarios, Archiveros y Arqueólogos, 1974, pp. 443-449.

«Dos cuentos tunecinos de temática sociorreligiosa: Las ventanas y La Llamada a la Oración del Alba, de Mahmoud Tarchouna», Almenara, 5-6, 1974, pp. 237-268.

«Arabic Studies in Spain Today», Middle East Studies Association Bulletin, 8, 2, 1974, pp. 1-7.

«Producción tunecina y argelina sobre Historia de España desde la Independencia (1956-1962)», Indice Histórico Español, XV, 56bis, 1969 [1975], pp. XI-LXII. (Con M. Benali y A. Gafsi.)

«Taqrir hawla Al-'alaqat bayna Isbaniya wa-l-Magrib sanat 1912», Revue d'Histoire Maghrébine, 4, 1975, pp. 91-96.

«Los Nombres del Profeta en la Teología Musulmana», Miscelánea Comillas, XXXIII, 63, 1975, pp. 149-203.

Bibliographie tunisienne concernant l'histoire de l'Espagne (1956-1973), Túnez, Institut National d' Archéologie et d'Art, 1975. (Con M. Benali y A. Gafsi.)

, Ecrits relatifs à l'histoire de l'Espagne Publiés en Algerie de 1962 à 1973, Argel, S.N.E.D.- Bibliothèque Nationale, 1976. 
«Hawla thalatha a dat gayr ma'rufa min al-'alaqāt at-tārijiyya bayna Annaba wa-Isbāniyya», Al-Asala, V, 1976, pp. 110-121.

«Las relaciones hispano-magrebíes en 1812, según un informe contemporáneo», Almenara, 9, 1976, pp. 73-81.

«Une importante carte espagnole de l'ouest algérien», Revue d'Histoire Maghrébine, 5, 1976, pp. 81-86.

«El congreso islamo-cristiano de Córdoba (septiembre 1974)», Concilium, número especial Cristianos y Musulmanes, 116, 1976, pp. 424-427.

«Notice d'un fonds de lettres officielles algériennes à fin XVIIIe siècle/début du XIIIe siècle de l'Hégire (en francés y en árabe)», Al-Watā'iq Al-Wațāniyya/Archives Nationales, 6, 1977, pp. 67/71-69/74.

«El Cid = El León ¿Epíteto Árabe del Campeador?», Hispanic Review, 45, 1977, pp. 67-75 [reed. Sharq Al-Andalus. Estudios Árabes, 7, 1990, pp. 227-236].

"Catálogo de 35 manuscritos árabes de la Biblioteca March», Fontes Rerum Balearium, 1, 1977, pp. 405-416.

«Mahoma, el hombre histórico y sus valores», Études Philosophiques et Littéraires. Revue de la Société de Philosophie du Maroc, 2, 1977, pp. 68-82.

"Mulahassat ab Isbani Yazuru Wahran fi ahd Mustafa Bu Salagim», Revue d' Histoire Maghrébine, 12, 1978, pp. 191-201. (Con H. Oueslati.)

«Reflexiones sobre la insersión social de los españoles en el Mágreb a partir de la Baja Edad Media», II Congreso Internacional de Estudios sobre las Culturas del Mediterráneo Occidental, Barcelona, Universidad de Barcelona, 1978, pp. 161-165.

«Relations Tuniso-Espagnoles au XIXe siècle: Documents et synthèse», Les Cahiers de Tunisie, XXVI, 101-102, 1978, pp. 183-216. (Con A. El-Gafsi.)

Autobiografia $i$ atacs als partidaris de la Creu, per Anselm Turmeda (Introducció i Traducció), Barcelona, Curial, 1978. (Con Ignasi Riera.)

, Oran et L'ouest Algerien Au 18ème Siècle d'après Le Rapport Aramburu, Argel, S.N.E.D. - Bibliothèque Nationale, 1978. (Con Mohammad el Korso.) «Takdir al-masiḥ̄n li-nabī Muhammad», Al-'Arabī, 236, 1978, pp. 88-91. «Les Etudes Árabes en Espagne Institutions, Chercheurs, Publications», Annuaire de L'Afrique du Nord, XV, 1976 [1978], pp. 1015-1029.

«El filósofo Ortega y Gasset y lo árabe. Introducción a una lectura de su texto sobre Ibn Jaldun y Melilla», Revista del Instituto Egipcio de Estudios Islámicos en Madrid, XIX, 1976-1978, pp. 71-114.

«Trabajos actuales sobre la comunidad de moriscos refugiados en Túnez, desde el siglo XVII a nuestros días», en Actas del Coloquio Internacional sobre Literatura Aljamiada y Morisca (Oviedo, 1972), Madrid, Gredos, 1978, pp. 427-446. 
"Note sur les forteresses hispaniques au Maghreb», Revue d'Histoire Maghrébine, 13-14, 1979, pp. 56-101.

«Recherches sur les Moriscos Andalous au Maghreb (Bilan et Perspectives)», Revue d'Histoire Maghrébine, 13-14, 1979, pp. 21 / 26-98/99. (Con M. Boughanmi, A. Gafsi y N. Halawi.)

«Resumen de la doctrina musulmana», Actualidad catequética, 94, 1979, pp. 87-109. (Con Ahmad El Agha.)

«Los Estudios Árabes en España», Revista Medio Oriente Informa, 7, 1979, pp. 46-47.

Ma'âhidât al silm al-awwwal al-Isbâniya al-Libiya Al-ma'qûda (1784 M./1198 H.), Trípoli, Marqaz Yihad Al-Libiyiin li-Dirasat at-Tarijiyya, 1980.

, «Ma'âhidât al silm al-awwal al-Isbâniya al-libiya. Le Premier Traité de Paix Hispano-Lybien (1784/ 1198)», Revue d'Histoire Maghrébine, 17-18, 1980, pp. 33-68.

«Los Soler menorquines en el Mediterráneo islámico (Magreb y Oriente) y la expansión mediterránea de los menorquines», Revista de Menorca, LXXI, 1980, pp. 106-111.

, «El topónimo Guardamar ('Río de las Dunas'), Valdemoro ('Río Amargo') y Mesleón ('Posada de Fuentes'). Tres topónimos árabes romanceados», Revista del Instituto de Estudios Alicantinos, 29, 1980, pp. 205-214.

«Improbables orígenes islámicos de la Inquisición y opinión de musulmanes sobre ella», en J. PÉREZ VILLANUEVA (ed.), La Inquisición Española. Nueva Visión, Nuevas Perpectivas, Madrid, Siglo XXI, 1980, pp. 29-38.

"Muhammad, ar-rayul at-ta'riji wa qiyama-hu», Études Philosophiques et Littéraires, 4, 1979-1980, pp. 33-46.

"Traduccions persa, turca, alemanya i catalana de La "Tuhfa" de Turmeda», Randa. Homenatge a Francesc de B. Moll, 11, 3, 1980, pp. 141-144.

"Nouveaux documents sur les andalous en Tunisie au début du XVIIIe siècle», Revue d'Histoire Maghrébine, 17-18, 1980, pp. 79/108-137/140.

«Fuentes españolas de Historia de Argelia (Siglos XVI-XVIII)», Anales de la Universidad de Alicante. Historia Moderna, 1, 1981, pp. 141-149.

«Notas sobre el lingüista Ibn-Sidah y la historia de Denia y su región en el s. XI», Revista del Instituto de Estudios Alicantinos, 15, 1981, pp. 161-172.

«El Manuscrito 'Errores de Los Moriscos de Granada' (Un núcleo criptomusulmán en el primer tercio del siglo XVIII)», Fontes Rerum Balearium, 3, 1979-1980 [1981], pp. 235-247. (Con Ma Soledad Carrasco Urgoiti.)

"Mahoma: el hombre histórico y sus valores», en Acción Americano-Árabe. Selección de Textos, Brasilia, Comporart Limitada, 1981, pp. 403-414.

«Lo moro, lo morisco y los moriscos en la provincia de Alicante», Alcoy. Revista de Moros y Cristianos, 1981, pp. 102-103. 
«Publicaciones españolas sobre el Magreb árabe (1978-1979)», Estudios de Asia y África. XVI, 47, 1981, pp. 161-176.

«Improbables origines islamiques de l'Inquisition espagnole et opinions de musulmans sur elle», Revue des langues romanes, LXXXV, 1981, pp. 101-114. «Problemas y reflexiones sobre el califato en al-Andalus», Revista del Instituto Egipcio de Estudios Islámicos en Madrid, XXI, 1981-1982, pp. 59-73.

«¿Hubo mozárabes en tierras Valencianas? Proceso de islamización del levante de la Península (Sharq Al-Andalus)», Revista del Instituto de Estudios Alicantinos, 36, 1982, pp. 7-31. (Con Enrique Llobregat.)

«Importancia de la historia árabe en Denia», Dianiumn: revista universitaria de ciencias y humanidades, 1, 1982, pp. 45-50.

«Orígenes de la invasión cordobesa de Mallorca en 792», en Estudis de prehistòria, de història de Mayurqa i d'història de Mallorca dedicats a Guillem Rosselló i Bordoy, Palma de Mallorca, Universitat, 1982, pp. 111-129.

_. Les nouveaux sur les relations de l'emir Abdelkader avec l' Espagne et ses gouverneurs militaires à Mélilla, Constantina, Dar al-Baht, 1982. (Con Yahya Bouaziz.)

«Les II Journées de culture arabe et islamique de Madrid (9-13 decembre 1980)», Annuaire de l'Afrique du nord, XVIII, 1979 [1982], pp. 997-998.

«Publications espagnoles sur le Maghreb (1978-1979)», Annuaire de l'Afrique du nord, XVIII, 1979 [1982], pp. 1123-1133.

«El derecho político musulmán y su influencia en la formación de Álava (siglos VIII-XI)», en La formación de Álava: 650 aniversario del Pacto de Arriaga (1332-1982), Vitoria, Diputación Foral de Álava, 1982, vol. I, pp. 303-314. «Las dos estelas árabes del museo de Alcoy», Alcoy, 1982, pp. 86-87. (Con Slimane-Mustafa Zbiss.)

«Le milieu hispano-moresque de l'évangile islamisant de Barnabé (XVIXVIIe s.)», Islamochristiana, 8, 1982, pp. 159-183.

«Intereses árabes e intereses españoles en las paces hispano-musulmanas del s. XVIII», Anales de Historia Contemporánea. Universidad de Murcia, 1, 1982, pp. 7-17 [trad. francesa en Studia Islamica, LVII, 1983, pp. 147-161].

Toponimia mayor y menor de la provincia de Alicante. Listado por municipios, Alicante, Caja de Ahorros Provincial de Alicante, 1983. (Con M.J. Paternina y A. Couto). (Con Juan Luis Román del Cerro.)

- Moros y moriscos en el Levante peninsular (Sharq Al-Andalus). Introducción bibliográfica, Alicante, Instituto de Estudios Alicantinos, 1983. (Con M.J. Paternina y A. Couto.)

Anselm Turmeda, Palma, Ajuntament de Palma, 1983.

, Etudes sur les morisques andalous, Túnez, Institut National d'Archeologie et d'Art, 1983. (Con S.M. Zbiss, A. Gafsi y M. Boughanmi.) 
"Nouveax documents sur les andalous en Tunisie au debut du XVIIIe siècle», en Etudes sur les morisques andalous, pp. 57/67-90/70.

Le Cid, personage historique et litteraire. Anthologie de textes arabes, espagnols, français et latins avec traductions, Paris, Maisonneuve et Larose, 1983. (Con Suzanne Guellouz.)

«Nota sobre la correspondencia inédita del emir 'Abdalkáder de Argelia con España, en visperas de su rendición (1847)», Anales de la Universidad de Alicante. Historia Contemporánea, 1, 1983, pp. 231-239.

«Africanismo nuevo y viejo en España: un coloquio en la U.N.E.D. de Madrid», Anales de la Universidad de Alicante. Historia Contemporánea, 2, 1983, pp. 269-271.

"Costas alicantinas y costas magrebíes: el espacio marítimo musulmán según los textos árabes», Sharq Al-Andalus. Estudios Árabes, 3, 1983, pp. 25-31.

«Les ottomans et l'insertion au Maghreb des andalous expulses d'Espagne au XVIIème Siècle», Revue d'Histoire Maghrébine, 31-32, 1983, pp. 165-173.

, «La cultura araba e la cultura spagnola: le traduzioni», Islam, storia e civiltà, II, 4, 1983, pp. 157-165.

«Las instituciones islámicas fundamentales», Misiones extranjeras, 75, 1983, pp. 469-471.

«El esplendor de al-Andalus, reflejo del esplendor fatimí en el siglo XIV», Actas del IV Coloquio Hispano-Tunecino (Mallorca, 1979), Madrid, Instituto Hispano-Árabe de Cultura, 1983, pp. 79-82.

«La Alfama de Benissa, baños árabes», Tercer Centenari Purissimna Xiqueta, Benissa, Ajuntament de Benissa, 1984, s.p.

"Problemas y reflexiones sobre el califato en al-Andalus», Anuario de Historia del Derecho Español, 53, 1983 [1984], pp. 569-582.

"Attitudes politiques de Tunis dans le conflit entre aragonais et français en Sicilie autour de 1282», La società mediterranea all'epoca del vespro. XI Congresso di Storia della. Corona d'Aragona. Palermo-Trapani-Erice 25-30 aprile 1982, Palermo, Accademia di scienze, lettere e arti, 1983, vol. II, pp. 597-601.

" «La vie publique musulmane: entre el respect de la profession de foi et l'acceptation de valeurs extra-islamiques", Acts of the 17th International Conference for the Sociology of Religion, London, C.I.S.R., 1983, pp. 131-150 [reed. en Le défi du fondamentalisme islamique, Genêve, Labor et Fides, 1988, pp. 53-62; trad. española en Encuentros Islamo-cristianos, 140, 1983].

, «El padre Félix $M^{a}$ Pareja y los eclesiásticos en el arabismo español del siglo XX», Estudios Eclesiásticos, 59, 1984, pp. 217-225.

«Mutxamel / Muchamiel (Alacant): origen aràbic d'aquest topònim», Societat d'Onomàstica. Butlletí interior, 16, 1984, pp. 15-17.

«Los beréberes y la arabización del País Valenciano», Quaderns de filologia. Miscel-lània Sanchis Guarner, 1, 1984, pp. 91-100. 
, «Dos textos moriscos bilingües (árabe y castellano) de viajes a Oriente (1395 y 1407-1412)», Hespéris-Tamuda, 20-21, 1982-1983 [1984], pp. 25-112.

, «Un cuaderno de aprender árabe en Elche, de 1768», Sharq Al-Andalus. Estudios Árabes, 1, 1984, pp. 167-168.

, «Funciones ganaderas de los albacares, en las fortalezas musulmanas», Sharq Al-Andalus. Estudios Árabes, 1, 1984, pp. 47-54.

"Alguns aspectos de la morofília literaria actual al País Valencià», Sharq AlAndalus. Estudios Árabes, 1, 1984, pp. 169-172.

«Dos literatos árabes viajan por Sharq Al-Andalus: Saqib Arslam (1939) y Hussayn Munis (1963)», Sharq Al-Andalus. Estudios Árabes, 1, 1984, pp. 173-184.

«Bibliografía sobre temas árabes de Sharq Al-Andalus (Levante de al-Andalus)», Sharq-al-Andalus. Estudios Árabes, 1, 1984, pp. 213-248. (Con Francisco Franco Sánchez.)

«Alacant àrab i els seus mercats», Fogueres de Sant Joan, 1984, pp. 72-73.

«El primer tratado de paz hispano-libio de 1784 (1198 h.)», Hispania, XLIV /157, 1984, pp. 277-319.

«Nuevos documentos sobre los descendientes de moriscos en el siglo XVIII», Studia Historica et Philologica in Honorem M. Batllori, Roma, Instituto Español de Cultura, 1984, pp. 195-228.

«Jawatir min ayl id miawi isbanī-arabī», Al-Karmel, XIII, 1984, pp. 111-115.

«Plans et cartes hispaniques de la Algérie», Al-Wața'iq al-Wataniyya. Archives Nationales. Actes du séminaire international sur les sources espagnoles de l'histoire algérienne, 10/11, 1984, pp. 55-69.

«Les morisques, vus à partir des communautés mudéjares précédentes», Les morisques et leur temps, París, CNRS, 1984, pp. 29-41.

, «Fonction du califat dans la Communaté islamique: cas d'al-Andalus», Islam communautaire (al-Umma). Concept et réalités, Genêve-Paris, Publications Orientalistes de France, 1984, pp. 49-66.

«L'identité onomastique et linguistique des morisques», en Abdeljelil TEMIMI (ed.), Actes du II Symposium International du C.I.E.M.: Religion, Identité et Sources Documentaires sur les Morisques Andalous, Túnez, Institut Supérieur de Documentation, 1984, vol. I, pp. 269-279.

«La expedición para la toma de Orán (1732) y su seguimiento en Túnez», Sharq Al-Andalus. Estudios Árabes, 2, 1985, pp. 11-18.

«Un 'modelo operativo' de urbanismo musulmán», Sharq Al-Andalus. Estudios Árabes, 2, 1985, pp. 137-149.

«Estudio del texto de al-Idrisi sobre Alicante», Sharq Al-Andalus. Estudios Árabes, 2, 1985, pp. 215-232. 
«Max Aub et les écrivains espagnols "exilés" en Algérie», en J. DÉjEux et D.H. PAGEAuX (eds.), Espagne et Algérie au XXe siècle. Contacs culturels et création littéraire, Paris, L'Harmattan, 1985, pp. 125-139.

Els noms àrabs de Benidorm i la seua comarca, Benidorm-Alacant, Ajuntament de Benidorm-Universitat d'Alacant, 1985 [trad. española simultánea]. (Con María Jesús Rubiera.)

"Arabismos en el manuscrito castellano del morisco tunecino Ahmed alHanafi», Homenaje a Alvaro Galmés de Fuentes, Madrid-Oviedo, Ed. GredosUniversidad de Oviedo, 1985, vol. II, pp. 515-527.

«Bibliografía sobre temas árabes del Sharq Al-Andalus (Levante de al-Andalus). Apéndice II», Sharq Al-Andalus. Estudios Árabes, 2, 1985, pp. 279-299. (Con Francisco Franco Sánchez.)

_ «Tres culturas o tres religiones?», Encuentro Islamo-Cristiano, 164, 1985.

«Elementos árabes en el urbanismo de Benissa», Revista de Fiestas, 1985, s.p.

«Los cristianos toledanos bajo dominación musulmana», en Simposio Toledo hispano-árabe, Toledo, Colegio Universitario de Toledo, 1986, pp. 129-133. (Con María Jesús Rubiera.)

, «stat actual dels estudis de toponímia valenciana d'origen àrab», Xe Col-loqui General de la Societat d'Onomàstica. Ier d'Onomàstica Valenciana. Societat d'Onomàstica. Butlletí interior, 54-55, 1986, pp. 420-426. (Con María Jesús Rubiera.)

«Origen de 'raimat'», Societat d'onomàstica. Butlletí interior, 25, 1986, p. 137. «Posible origen vial el nombre de lloseta», Lloseta, 1986, p. 183.

«El árabe y la lengua catalana», Temas árabes, 1986, pp. 191-197.

, «Hommage hispanique à Louis Gardet», Islamochristiana, 12, 1986, pp. 23-26. «Études d'éléments urbanistiques d'al-Andalus», Les Cahiers de Tunisie, 34, 1986, pp. 131-138.

«La sofra (sujra) en el Sharq al-Andalus antes de la conquista catalano-aragonesa», Sharq Al-Andalus. Estudios Árabes, 3, 1986, pp. 33-37. (Con M.J. Rubiera.)

«El portulano de Ibrahim de Murcia», Sharq Al-Andalus. Estudios Árabes, 3, 1986, pp. 167-168.

«La islamizacion de al-Andalus: mozárabes y neomozárabes», Revista del Instituto Egipcio de Estudios Islámicos en Madrid, 23, 1986, pp. 171-179.

Murāsalāt al'am̄̄r 'Abd al-Kādir ma' 'Isbāniā wa ḥukkāmihā al-'askariyȳ̄n bi Mallīla / Correspondance de l'emir Abdalkader avec l'Espagne et ses gouverneurs militaires à Melilla, Argel, Dīwān al-Maṭ bū'āt al-Ŷāmi'iyya, 1986. (Con Yahya Buaziz.)

«Un manuscrito narrativo normativo árabe y aljamiado: problemas lingüísticos, literarios y teológicos de las traducciones moriscas», en Abdel- 
jelil Temimi (ed.), Actes de la première Table Ronde du C.I.E.M. sur La Littérature aljamiado-morisque: hybridisme linguistique et univers discursif, Túnez, Centre de Recherches en Bibliothéconomie et Sciences de l'Information, 1986, pp. 35-45 [trad. árabe pp. 39-47].

«Influences de la familie musulmane sur des comportements familiaux en Espagne ainsi que dans les autres pays non-musulmans du bassin de la Méditerranée», Families musulmanes et modernite. Le defi des traditions. Revue internationale de droit comparée, 38, 4, 1986, pp. 195-213.

, «Etudes d'elements urbanistiques d'al-Andalus», Les Cahiers de Tunisie, XXIV, 137-138, 1986, pp. 131-138.

«Bibliografía sobre temas árabes del Sharq Al-Andalus (Levante de al-Andalus). Apéndice III», Sharq Al-Andalus. Estudios Árabes, 3, 1986, pp. 267-286. (Con Francisco Franco Sánchez.)

«Relacions dels països catalans amb el món musulman», Revista de Catalunya, 5, 1987, pp. 49-62.

«Los grandes mogoles: imperio de la India (1526-1858)», Historia 16, 140, 1987, pp. 49-60.

«Tortosa, un lloc estrategic a al-Andalus», $D(t), 2,1987$, pp. 13-17.

«El islam aragonés, un islam de frontera», Turiaso, 7, 1987, pp. 9-22.

«El mosaico romano de Petrer y la existencia de unos posibles baños árabes», Páginas de nuestra historia, 7, 1987. (Con M.J. Rubiera.)

«Viaje por otras Benisas árabes», Mil.lenari Benissa, 7, 1987.

Xàtiva musulmana (segles VIII-XIII), Xàtiva, Ajuntament de Xàtiva, 1987. (Con M.J. Rubiera.)

, Jésus otage. Juifs, chrétiens et musulmans en Espagne (VIIe-XVIIe s.), Paris, Les éditions du Cerf, 1987.

"Un nuevo texto mallorquín de az-Zuhri y ganadería en las Baleares», Les illes orientals d'al-Andalus, Palma de Mallorca, Institut d'Estudis Baleàrics, 1987, pp. 47-53. (Con J.I. Sáez Castán.)

«Precisiones sobre instituciones musulmanas de las Baleares», Les illes orientals d'al-Andalus, pp. 73-87.

«Sobre la arabizacion de los nombres de las Islas Baleares: Maiorica, Minorica, Ebusa-Ibisa, Furmentera-Formentera», Les illes orientals d'al-Andalus, pp. 173-179. (Con Sol Martínez y Martínez-Tercero.)

«Los cristianos en las Baleares musulmanas», Les illes orientals d'al-Andalus, pp. 133-143.

«Els ports d'Alacant i Túnez en el segle XVIII», Materials del congres d'estudis del Camp d'Alacant, Alicante, Diputación Provincial de Alicante, 1987, pp. 171-232. 
«La situación urbanística de la tumba de Anselm Turmeda en Túnez», Studia in honorem prof. M. de Riquer, Barcelona, Quaderns Crema, 1987, pp. 637-641.

«Funciones de enseñanza de las dos mezquitas sobre las murallas de la Alhambra», Homenaje al prof. Darío Cabanelas Rodriguez O.F.M., con motivo de su LXX aniversario, Granada, Universidad de Granada, 1987, pp. 183-186. «La dualidad Campello-Fahs en el espacio agrícola de Al-Andalus (Alicante, Castalla, Pedreguer, Madrid)», Sharq Al-Andalus. Estudios Árabes, 4, 1987, pp. 159-173.

«Correspondencia del arabista mallorquín Artigas con el valenciano Borrull sobre historia árabe valenciana (1828-1829)», Sharq Al-Andalus. Estudios Árabes, 4, 1987, pp. 235-239.

«Bibliografía sobre temas árabes del Sharq al-Andalus (Levante de al-Andalus). Apéndice IV», Sharq Al-Andalus. Estudios Árabes, 4, 1987, pp. 291349. (Con Francisco Franco Sánchez.)

«La tumba de un santo musulmán en Benifato», Alcoy, 1988, pp. 164-165. , «Etudes hispaniques actuels sur l'Evangile islamisant de Barnabé», AlMasâq, 1, 1988, pp. 33-38.

«Viaje por otras Benissa árabes», Milllenari Benissa, Benissa, Ajuntament de Benissa, 1987, s.p.

«El significat etimològic de Petrer: cami empedrat», Societat d'onomàstica. Butlletí interior, 31, 1988, pp. 10-11.

Aigua i poblament musulmá. Agua y poblamiento musulmán, Benissa, Ajuntament de Benissa, 1988. (Ed.)

, «El agua en el Derecho musulmán», en Aigua i poblament musulmá. Agua y poblamiento musulmán, pp. 13-19.

- Planos y mapas hispánicos de Argelia. Siglos XVI-XVII, Madrid, Ministerio de Asuntos Exteriores, 1988. (Con J.B. Vilar Ramírez.)

«La cartografía mediterránea que fomenta racismos», Canelobre [ $\mathrm{n}^{\circ}$ especial sobre el Mediterráneo], 12/13, 1988, pp. 39-44.

, «Constitución de rábitas en la costa de Almería: su función espiritual», Homenaje al Padre Tapia. Almería en su Historia, Almería, Cajalmería, 1988, pp. 231-235.

«L'ordenacio del territori del País Valencià abans de la conquesta, segons Ibn-al-Abbâr (segle XIII)», Sharq Al-Andalus. Estudios Árabes, 5, 1988, pp. 41-67.

"Juan Vernet. Tres textos sobre antroponimia árabe catalana», Sharq AlAndalus. Estudios Árabes, 5, 1988, pp. 201-202. (Con J.B. Vilar Ramírez.)

«Bibliografía sobre temas árabes del Sharq Al-Andalus (Levante de al-Andalus). Apéndice V», Sharq Al-Andalus. Estudios Árabes, 5, 1988, pp. 259-285. (Con J.B. Vilar Ramírez.) 
«Santa Pola en època àrabe», Revista de Festes, Santa Pola, 1988, s.p.

«Caracterización del exilio musulmán: la voz de mudéjares y moriscos», Destierros aragoneses. I Judíos y moriscos, Zaragoza, Institución Fernando el Católico, 1988, pp. 217-228.

«A modo de introducción. El escritor Ibrayhim Taybili y los escritores musulmanes aragoneses», en Luis F. BERNABÉ PONS, El cántico islámico del morisco hispanotunecino Taybili, Zaragoza, Institución Fernando el Católico, 1988, pp. 5-26.

"Congresos y publicaciones de historia árabe en época otomana (Túnez)», Awrâq, IX, 1988, pp. 217-221.

«Bibliografía sobre temas árabes del Sharq al-Andalus (Levante de al-Andalus). Apéndice V», Sharq Al-Andalus. Estudios Árabes, 5, 1988, pp. 259-285. (Con Francisco Franco Sánchez.)

«Novedades bibliográficas sobre el Corán y Mahoma», Sharq Al-Andalus. Estudios Árabes, 6, 1989, pp. 235-240. (Con Luis F. Bernabé.)

«Topònims àrabs a Alacant i a Malta: Benissa de Alacant y Benghixa de Malta», Canelobre, 13-13, 1998, pp. 196-198.

«Rites musulmans opposés aux rites chrétiens dans deux textes de morisques tunisiens: Ibrahim Taybili et Ahmad Al-Hanafi», en A. TEMIMI (ed.), Actas del III Simposio Internacional de Estudios Moriscos. Las Prácticas Musulmanas de los Moriscos Andaluces (1492-1609), Zaghouan, CEROMDI, 1989, pp. 71-74.

«El binomi àrab-mossàrab, al-Fahs-el Campello, a Lleida», Societat d'Onomàstica. Butlletí interior, Barcelona, 35, 1989, p. 32.

«Pregó. Festes de la Mercè 1983», Pregons, Barcelona, Ajuntament de Barcelona, 1989, pp. 7-13.

«Note sur l'eau dans les recherches sur l'urbanisme musulman en Espagne», en Jean-Louis MièGE, Martine PerneY y Christiane Villain-Gandossi (eds.), L'eau et la culture populaire en Mediterraneé, Aix-en-Provence, Institut d'histoire des pays d'outre-mer, Universite_de Provence, 1989, pp. 23-25. «Préface», en Edgar Weber y Georges ReYNAud, Croisade d'hier, Djihad d'aujourd'hui. Théorie et pratique de la violence dans les rapports entre l'Occident chrétien et l'Orient musulman, Paris, Les éditions du Certf, 1989, pp. 9-11.

《Tolerància i intolerància islámica», Cultura, Barcelona, 1989, pp. 14-15.

«Las Fiestas de Moros y Cristianos hoy: carácter festivo, morófilo y antibélico», Moros y cristianos. San Blas, 1989, pp. 24-25.

«Sobre el nombre árabe del castillo de la Atalaya de Villena», Revista de Fiestas, Villena, 1989, p. 110.

«Unas 'huestes del califa' desmilitarizadas», Revista de fiestas. Las huestes del califa, Elx, 1989, p. 25. 
«Discurso de mantenedor», Moros y cristianos. Fiestas patronales, Crevillent, 1989 , p. 5.

750 anys. Civilització trencada: l'Islam valencià, València, Generalitat Valenciana, 1989. (Dir., con Edelmir Galdón.)

"Nota sobre la etimología árabe-islámica de 'riesgo'», Sharq Al-Andalus. Estudios Árabes, 6, 1989, pp. 185-192.

«La revolució libia: un testimoni personal», Espurnall internacional, Barcelona, 1989, p. 17.

Baños árabes en el País Valenciano, Valencia, Generalitat Valenciana, 1989. (Dir.) , «Introducción», Baños árabes en el País Valenciano, pp. 9-10.

, «Estructura y funciones de los baños islámicos», Baños árabes en el País Valenciano, pp. 11-24.

«Mobiliario de los baños árabes», Baños árabes en el país Valenciano, pp. 79-82.

, «Zaghouan selon un voyageur espagnol du XVIII siècle», El Hanaya, 3, 1989, pp. 3-7.

«La mujer en el espacio urbano musulmán», La mujer en al-Andalus. Reflejos históricos de su actividad y categorías sociales, Madrid-Sevilla, Universidad Autónoma de Madrid - Editoriales Andaluzas Unidas, 1989, pp. 53-60.

«El Islam», Historia de las Baleares, Palma de Mallorca, Formentor, 1989, vol. II, pp. 208-240.

«Un cas d'opinion publique Maghrebine: la prise d'Oran par les espagnols, vue de Túnez (1732)», Revue d'histoire Maghrebine, 1989, pp. 5-10.

, «Al-Andalus et le Maghreb. Frontière de l'islam dans la conscience musulmane, medievale et moderne», Horizons Maghrebins, 14-15, 1989, pp. 28-32. «Hommage à Massignon», Horizons Maghrebins, 14-15, 1989, pp. 205-207. , «Estructura, evolució i esplendor de les taifes Valencianes», En torno al 750 aniversario: antecedentes y consecuencias de la conquista de Valencia, Valencia, Consell Valencià de Cultura, 1989, pp. 129-140.

«Influències àrabs en l'alimentació de la Marina Nord», Aguaits. Revista d'investigacio $i$ assaig, 3, 1989, pp. 17-21.

«Prólogo», en José NAVARro PayÁ, Episodios que conmemoran las Fiestas de Moros y Cristianos, Petrer, 1989, pp. 9-12.

, «Congresos y publicaciones de historia árabe en época otomana», Awrâq, IX, 1988, pp. 217-221.

«Els moriscos valencians a l'exili després de l'expulsió del 1609», Afers, IV, 7, 1989, pp. 207-214. (Con Luis F. Bernabé.)

«El català en el Magreb àrab. Els moriscos expulsats», en Antoni FERRANDO (coord.), II Congrés Internacional de la Llengua Catalana, València, Universitat de València, 1989, pp. 385-388. 
«Un logos cristià enfront de l'Islam: Eiximenis escrivint sobre Mahoma», Miscel-lània Joan Fuster, Barcelona, Publicacions de l'Abadía de Montserrat, 1990, pp. 59-75.

«Almunia: el seu significat en epoca àrab», Antistiana, 1990, pp. 3-6.

«Le lexique religieux des morisques et la litterature aljamiado-morisque», en Louis CARDAillac (dir.), Les morisques et l'Inquisition, Paris, Publisud, 1990, pp. 51-64.

«Principes chrétiens et principes musulmans face au probleme morisque», en Louis CARDAillac (dir.), Les morisques et l'Inquisition, Paris, Publisud, 1990, pp. 37-49.

«Toponimia àrab i estructura comarcal: el Penedés», Societat d'Onomàstica. Butlletí interior, 1990, pp. 76-82 [tb. en Antistiana, 1990, pp. 2-13].

«Préface», en Muhammad ABU-RuB, La poesie galante andalouse au XIè siècle: typologie, Paris, Asfar, 1990, pp. 13-18.

"Alcanar i la seua regió a l'época musulmana», I Congrés d'Història d'Alcanar, Alcanar, Ajuntament d'Alcanar, 1990, pp. 59-68. (Con Luis F. Bernabé.)

«Bibliografia sobre temas árabes del Sharq al-Andalus (Levante de al-Andalus). Apéndice VI», Sharq Al-Andalus. Estudios Árabes, 7, 1990, pp. 245-280. (Con Francisco Franco Sánchez.)

«Etimología árabe del Cid como antropónimo ("el león”) y como topónimo ("el señor y/o gobernador almohade")», Sharq Al-Andalus. Estudios Árabes, 7, 1990, pp. 157-169.

«Relaciones del cónsul británico Morgan con descendientes de moriscos en el Magreb (siglo XVIII)», Estudios de Filología Inglesa: homenaje al Dr. Pedro Jesús Marcos Pérez, Alicante, Universidad de Alicante, 1990, pp. 615-620.

«La vie intellectuelle en espagnol des morisques au Maghreb (XVII siècle)», Revue d'histoire maghrébine, Zaghouan, 59-60, 1990, pp. 73-78.

Ibn al-Abbâr. Politic i escriptor àrab valenciá, Valencia, Generalitat Valenciana, 1990. (Ed. con Jesús Huguet.)

«La caiguda de Valencia i altres caigudes d'al-Andalus», Ibn al-Abbâr. Polític i escriptor àrab valenciá, Valencia, Generalitat Valenciana, 1990, pp. 19-42.

«Ondara, una capital comarcal d'época arab», Ondara. Festes majors, Ondara, 1990, pp. 0-2.

«Nota sobre consecuencias hispano-magrebíes de la Revolución Francesa», Awrâq, 11, 1990, pp. 171-174.

"Diminutiu amb flexio interna arab en cognoms catalans: "curt", "cureyet" (Cocentaina, 1515)», A sol post. Estudis de llengua i literatura, 1990, pp. 133-138.

«Estudios sobre migraciones mediterraneas del siglo XVI al XX: Vilar, Bonmati, Bono, Bennasar, López Nadal, Cucchini», Sharq Al-Andalus. Estudios Árabes, 7, 1990, pp. 239-242. 
«Encuentro de revistas europeas de arabismo», Sharq Al-Andalus. Estudios Árabes, 7, 1990, pp. 323-324.

" «Actividades de la división de árabe de la Universidad de Alicante (1989)», Sharq Al-Andalus. Estudios Árabes, 7, 1990, pp. 305-309.

, «Quelques reflexions sur l'espace maritime euro-árabe mediterranéen», Al-Masâq, 3 1990, pp. 53-54.

, «Corrents islamiques aparents i amagats a la cultura catalana medieval», El debat intercultural als s. XIII i XIV, Actes..., Girona, 1990, pp. 107-116.

, «Espacios y sus funciones en la ciudad árabe», La ciudad islámica: ponencias y comunicaciones, Zaragoza, Institución Fernando el Católico, 1991, pp. 9-30.

, «Origines du concept de risque: de l'islam a l'Occident», Le risque et la crise, Malta, 1991, pp. 63-70.

«Prólogo/Préface», en J.B. VILAR, Mapas, planos y fortificaciones hispánicas de Túnez, Madrid, 1991, pp. 17-27.

, "Topònims d'origen antroponímic àrab de temps de la conquesta ( $\mathrm{Cid}$, Busot, Benimassot, Massoda, Benissoda, Benissaudet)», Societat d'Onomàstica. Butlleti interior, 44, 1991, pp. 619-627.

«Juan Vernet y los estudios islámicos», Anthropos, 117, 1991, pp. 34-35.

, «Pluralisme et tolerance: un modèle toledan», Tolede. XII-XIII. Musulmans, chrétiens et juifs: le savoir et la tolérance, Paris, 1991, pp. 241-251.

«Programme al-Andalus-1992», Islamochristiana, 1991, pp. 204-205.

«El Cid y los musulmanes: el sistema de parias / pagas, la colaboración de Aben-Galbon, el título del Cid-león, la posadita fortificada de Alcocer», en José Luis CORRAL LAFUENTE (coord.), El Cid en el valle del Jalón, Zaragoza, Institución Fernando el Católico, 1991, pp. 103-121.

«Problemas teológicos musulmanes y cristianos en el enfrentamiento de los ultimos musulmanes de españa con los poderes cristianos», Sharq Al-Andalus. Estudios Árabes, 8, 1991, pp. 89-95.

, "Al-Munastir d'Ifriqiyya et Al-Munastir de Xarq al-Andalus», Le patrimoine andalous dans la culture árabe et espagnole, Túnez, Université de Tunis, 1991, pp. 95-106.

«Conversió i narrativa oral islàmiques a les narracions literàries autobiogràfiques d'Anselm Turmeda», IX Col-loqui Intenacional de Llengua i Literatura Catalanes, Alicante, Universitat d'Alacant, 1991, vol. 1, pp. 78-82. «¿Hubo mozárabes en tierras valencianas? Proceso de islamización del Levante de la Península (Sharq al-Andalus)», en E. LlOBREGAT, Ilucant. Un cuarto de siglo de investigación histórico-arqueológica en tierras de Alicante, Alicante, Instituto de Cultura "Juan Gil-Albert", 1991, pp. 477-487. (Con Enrique Llobregat.)

, Los moriscos antes y después de la expulsión, Madrid, MAPFRE, 1992. 
«Las crónicas mozárabes», Historia 16, 1992, pp. 112-116.

«Pluralisme et tolérance, un modèle toledan?», Compréhension et échanges culturels euro-arabes, Strassbourg, Conseil de l'Europe, 1992, pp. 95-101.

«Mondes musulmans. Vivre au quotidien», en G. MARTINiÈre y C. VARELA (eds.), L'état du monde en 1492, Paris-Madrid, La Découverte-Sociedad Estatal para la Ejecución de Programas del Quinto Centenario, 1992, pp. 191-197.

«Nota sobre la bibliografía acerca de Xarc al-Andalus», Miscelánea de la Biblioteca Española de Tánger, 1992, pp. 53-57.

"Spain's commemoration of the fall of Granada», Studies in Interreligious Dialogue, 2, 1992, pp. 82-88.

"Els berbers i l'arabització del País Valencià», Miscel-lània Sanchis Guarner, Montserrat, Publicacions de l'Abadia de Montserrat, 1992, vol. I, pp. 467-492.

«Murcia, centro geopolítico de Xarc al-Andalus (Oriente de la Península)», en P. JimÉnEZ (ed.), El siglo de oro del islam en Murcia, Murcia, Comunidad Autónoma de Murcia, 1992, pp. 11-14.

"Mozarabs: an emblematic Christian Minority in islamic al-Andalus», en S.K. JAYYUSI, The Legacy of Muslim Spain, Leiden, E.J. Brill, 1992, pp. 148-170. «La chute de Grenade dans la conscience historique espagnole», Maroc-Europe, 3, 1992, pp. 225-232.

«Les mozárabes. Etat de la question», Revue du Monde Musulman et de la Méditerranée, 1992, pp. 30-50.

«Influences islamiques dans la théologie chrétienne mediévale: 1'adoptionisme espagnol (VIII siècle)», Islamochristiana, XVIII, 1992, pp. 55-72.

«Els noms àrabs de Dénia, Eivissa, Lleida i Xàtiva: problemes de transcripció i pronunciació», Societat d'Onomàstica. Butlletí interior, 50-51, 1992, pp. 60-63. (Con Josep Forcadell Saport.)

«Bibliografía sobre temas árabes del Sharq al-Andalus (Levante de al-Andalus). Apéndice VII», Sharq Al-Andalus. Estudios Árabes, 8, 1992, pp. 229-276. (Con Francisco Franco Sánchez.)

«El racismo norte-sur en los mapas», La vanguardia. Suplemento ciencia y tecnología, 1992, pp. 4-5.

«Pluralismo y tolerancia: ¿un modelo toledano?», Toledo, siglos XII-XIII. Musulmanes, cristianos y judios: la sabiduría y la tolerancia, Madrid, Alianza Editorial, 1992, pp. 251-261 [trad. alemana «Überlegungen zum religiösen Pluralismus (Muslime, Christen und Juden) und die Toleranz auf der iberischen Halbinsel im Mittelalter», en Reinhard KIRSTE, Paul SCHWARZENAU y Udo TwORUsCHKA (eds.), Wertewandel und religiöse Umbrüche, Religionen im Gespräch, 4, Balve, Zimmermann Druck + Verlag, 1996, pp, 365-378.

«Presentación-prólogo», J.B. Vilar, Los moriscos del reino de Murcia y obispado de Orihuela, Murcia, Academia Alfonso X el Sabio, 1992, pp. 9-11. 
«Mallorca bajo la autoridad compartida de bizantinos y árabes (siglos VIII-IX)», Asociación Hispano-Helénica. Homenaje a Juan Nadal, Atenas, Asociación Hispano-Helénica, 1992, pp. 143-149.

"Actualidad de Turmeda en la polémica islamo-cristiana en Francia», Awrâq, 1993, pp. 271-286 [trad. alemana «Die Aktualität von Anselm Turmeda in der islamisch-christilichen Polemik in Frankreich und Katalonien», en Reinhard KIRSTE, Paul SCHWARZENAU y Udo TwORUSCHKA (eds.). Hoffnungszeichen globaler Gemeinscraft, Religionen im Gespräch, 6, Balve, Zimmermann Druck + Verlag, 2000, pp. 182-192].

La ràpita islàmica: història institucional i altres estudis regionals, Sant Carles de la Ràpita, Ajuntament de Sant Carles, 1993. (Ed.)

«La Rápita islámica: Historia institucional», en La ràpita islàmica: història institucional $i$ altres estudis regionals [reed. en M. de EPALZA y F. FRANCO SÁNCHEZ (eds.), La Rábita en el Islam: estudios interdisciplinares, pp. 5-28].

«Aportación egipcia a la Islamología española (pasado, presente y futuro)», Revista del Instituto Egipcio de Estudios Islámicos en Madrid, XXV, 1993, pp. 61-65.

«Petrer en un nuevo texto árabe sobre la calzada Valencia-Murcia», Festes93, 1993, p. 2.

"Conversió i narrativa oral islàmiques a les narracions literàries autobiográfiques d'Anselm Turmeda (Abdàl-lah at-Tarjuman)», Actes del Novè Col-loqui Internacional de Llengua i Literatura Catalanes. Barcelona, Abadia de Montserrat, 1993, vol. 1, pp. 153-159 [trad. alemana «Arabisch-spanische Symbyose der Schrifsteller Anselm Turmeda/Abdallah at-Tarjuman und seine Wirkung», en Reinhard KIRSTE, Paul SCHWARZENAU y Udo TwORUSCHKA (eds.), Die dialogische Kraft der Mystischen, Religionen im Gespräch, 5, Balve, Zimmermann Druck + Verlag, 1998, pp. 280-292].

, «La ciutat àrab i l'estructuració comarcal dels seus topònims: el cas d'Ondara (Marina Septentrional)», Societat d'Onomàstica. Butlletí interior, Barcelona, 54-55, 1993, pp. 257-263.

«La espiritualidad militarista del islam medieval. El ribat, los ribates, las rábitas y los almonastires de al-Andalus», Medievalia, 3, 1993, pp. 5-18.

«Notes de sociologie religieuse mediévale: la disparation du christianisme au Maghreb et à al-Andalus», Mélanges offerts à Mohamed Talbi, Túnez, Université de Tunis, 1993, pp. 69-79.

" Ortega y Gasset: tensión e integración de lo árabe y lo europeo», Mundo árabe/mundo hispánico: creatividad e historia. Homenaje a Marcelino Villegas. Awrâq, Madrid, CSIC-ICMA, 1993, pp. 43-52.

«Al-Andalus et le Maghreb, frontière dans la conscience musulmane mediévale et moderne», Maroc-Europe, 4, 1993, pp. 205-210.

«Problemática de l'islam amb l'història», La problemática actual de l'islam, Alicante, Universidad de Alicante, 1993, pp. 43-52. 
«Juan Martínez Ruiz. 1922-1992», Aljamía, 5, 1993, pp. 15-25.

«La desaparición del cristianismo en el Magreb y en al-Andalus», Encuentro islamo-cristiano, 267, 1994, pp. 1-6.

«Influencias religiosas islámicas y su detección en el cristianismo latino-medieval», Revista del Instituto Egipcio de Estudios Islámicos en Madrid, XXVI, 1994, pp. 117-135.

«La moriscología como ciencia histórica, en la actualidad», L'expulsió dels moriscos. Conseqüiències en el món islàmic i en el món cristiá, Barcelona, Generalitat de Catalunya, 1994, pp. 9-15.

, «Les ràpites (râbita) islàmiques i la toponímia catalana», Societat d'onomàstica. Butlletí interior, 57, 1994, pp. 35-47.

, «Influències de la cultura d'al-Andalus al Magreb», en M.A. RoQuE (ed.), Les cultures del Magreb, Barcelona, 1994, pp. 63-73.

«El Corán, texto sagrado del islam», El Corán más pequeño del mundo, Alicante, 1994, p. 2.

«Problemática de l'islam amb la història», Sobre interculturalitat, 2, 1994, pp. 73-75.

«Toponímia àrab a Catalunya», Serra d'Or, 411, 1994, pp. 164-165.

L'islam d'avui, de demà i de sempre, Barcelona, Enciclopedia Catalana, 1994. (Dir.)

«L'islam de sempre», L'islam d'avui, de demà i de sempre, pp. 15-65.

«L'islam del segle XXI», L'islam d'avui, de demà i de sempre, pp. 311-334.

"Síntesi d'història de l'islam i Catalunya», L'islam d'avui, de demà i de sempre, pp. 361-376.

"Glossari de termes i noms islàmics», L'islam d'avui, de demà $i$ de sempre, pp. 399-418.

«Els musulmans a l'Estat Espanyol», L'islam d'avui, de demà $i$ de sempre, pp. 377-398. (Con Jordi Moreras.)

«Aspectos de la actividad de Doña María Jesús, en la Universidad de Alicante», Sharq Al-Andalus. Estudios Árabes, Homenaje/Hometagne a María Jesús Rubiera Mata, 10-11, 1993-1994, pp. 29-52.

«Sobre el origen islámico del adopcionismo: influencias musulmanas encubiertas en el cristianismo latino», Diálogo filosófico religioso entre cristianismo, judaísmo e islam durante la Edad Media en la Península Ibérica, Brepols, Société Internationale pour l'Étude de la Philosophie Mediévale, 1994, pp. 29-52.

«L'estudi comarcal dels topònims àrabo-catalans», Miscel.lània Germà Colon, Montserrat. Publicaciones de l'abadia de Montserrat, 1994, vol. 2, pp. 241-270. 
"Falta de obispos y conversion al islam de los cristianos de al-Andalus», $A l$ Qanțara, XV / 2, 1994, pp. 385-400.

«L'estructuració comarcal de la marina d'Ondara en època àrab (textos i topònims)», Aguaits. Revista d'investigació i assaig, 10, 1994, pp. 7-11.

"Lo andalusí y lo español en una revista tunecina moderna. 30 años de Hawliyat al-yami'a at-tûnisiya», Awrâq, XV, 1994, pp. 251-268.

«Études sur le ribat islamique. Sa spiritualite militaire et ses traces archéologiques en Espagne», Maroc-Europe, 6, 1994, pp. 129-146.

«Le modèle andalou: une tolérance intolerable?», en Thierry FABRE (ed.), L héritage andalou, Éditions de l'aube, 1995, pp. 117-122.

«La voz oficial de los musulmanes hispanos, mudéjares y moriscos, a sus autoridades cristianas: cuatro textos, en árabe, en castellano y en catalánvalenciano», Sharq Al-Andalus. Estudios Mudéjares y Moriscos, 12, 1995, pp. 279-297.

"Les symbioses culturelles à al-Andalus», en Jacques WAARDENBOURG (ed.), Scholarly approaches to religion, interreligious perceptions and islam, Berna, Peter Lang, 1995, pp. 293-304.

«Formación e investigación universitarias sobre el islam. Master de estudios éuro-árabes (Girona)», en Montserrat ABumalHAM (ed.), Comunidades islámicas en Europa, Madrid, Trotta, 1995, pp. 218-227.

«El islam en la Península Ibérica, medieval y moderna. Estudio multidisciplinar y su relación con la vivencia», 'Ilu.Revista de ciencias de las religiones, 0, 1995, pp. 63-69.

«Mutaciones urbanísticas debidas a la transformación de mezquitas en iglesias», VI Simposio Internacional de Mudejarismo. Teruel, 16-18 de septiembre de 1993, Teruel, Centro de Estudios Mudéjares, 1995, pp. 501-518.

«La costa como frontera militarizada del islam», Al-andalus y el Mediterráneo, Barcelona, Lunwerg Editores, 1995, pp. 57-65.

«Situations de conversion socioreligieuse dans les sociétés ibériques (VeXXe s.)», en Therèse ROLAND-GossELIN (ed.), Convertis à l'Islam, aujourd'hui, à Seville, Fondation pour le progrés de l'homme, 1995, 5-13, pp. 121-122 [trad. alemana «Situationen von sozioreligiöser Konversion in den iberischen Gesellschaften vom 5. - 20 Jahrhundert. Eine Übersicht», en Reinhard KiRSTE, Paul SCHWARZENAU y Udo TwORUSCHKA (eds.), Hoffnungszeichen globaler Gemeinscraft, Religionen im Gespräch, 6, Balve, Zimmermann Druck + Verlag, 2000, pp. 169-181].

, «Nota sobre Benimagrell, antropónimo árabe-alicantino del siglo XIII y topónimo actual de Alicante», Anales de la universidad de Alicante. Historia Medieval. Homenaje al prof. Juan Manuel del Estal en su jubilación académica, 9, 1995, pp. 53-67. 
«Bibliografía de mudéjares y moriscos», Sharq Al-Andalus. Estudios Mudéjares y Moriscos, 12, 1995, pp. 631-655. (Con Luis F. Bernabé Pons.)

«Un ejemplo de conjunto histórico-arquitectónico en liquidación: el sistema de fortificaciones españolas en Orán (1504-1791)», Aldaba, 26, 1995, pp. 345-366. (Con Juan Bautista Vilar Ramírez.)

«Accords officiels sur l'enseignement islamique dans les écoles et lycées, et reactions chrétiennes positives (janvier-mars 1996)», Islamochristiana, 22, 1996, pp. 211-213.

«Las simbiosis culturales de al-Andalus», Indian Journal of Spanish and Latino American Studies, IV,1-2, 1996, pp. 33-37.

«Las ciudades arábigo-musulmanas de la costa oriental de la Península Ibérica (Sharq-al-Andalus) y su función comercial», en D. ABULAFIA, Blanca GARí (eds.), En las costas del Mediterráneo Occidental. Las ciudades de la Península Ibérica y del Reino de Mallorca y el comercio mediterráneo en la Edad Media, Barcelona, Ediciones Omega, 1996, pp. 95-113. (Con María Jesús Rubiera Mata.)

«Islamic Social Stuctures in Muslim and Christian Valencia», en P. CHEVEDDEN, D. KagAy y P. PADILLA (eds.), Iberia and the Mediterranean World of the Middle Ages. Essays in honor of Robert I. Burns, S.J., Leiden, E.J. Brill, 1996, vol. 2, pp. 179-190.

«Sobre García Gómez como conferenciante y periodista. La autoría del Evangelio de San Bernabé», Awrâq, 17, 1996, pp. 121-133.

«L'Islam a Catalunya o l'Islam del sud?», L'Avenç. Revista d'història i cultura, 200, 1996, pp. 42-47.

«Instalación de moriscos en Anatolia (documento Temimi, de 1613)», Sharq Al-Andalus. Estudios Mudéjares y Moriscos, 13, 1996, pp. 145-157.

, «structuras de acogida de los moriscos emigrantes de España en el Mágreb (siglos XIII al XVIII)», Alternativas. Cuadernos de trabajo social, 4, 1996, pp. 35-58.

«Un obispo de Albarracín en tiempos del Cid y su contexto islamo-cristiano», Studium. Revista de humanidades. Homenaje al Profesor Antonio Gargallo, 3, I, 1997, pp. 113-134.

«Els musulmans a la Catalunya Vella. Els d'ara i els de fa 1.300 anys», De la ciência, del món i d'altres cultures: relacions internacionals, ciência, història de l'Islam i món àrab contemporani, 1997, pp. 127-138.

«L'islam i les seves adaptacions al segle XXI», Papers de fi de mil.leni, Olot, Miquel Plana Editor, 1997, pp. 1-31.

«Musulmans originaires d'al-Andalus dans les sociétés hispaniques européennes. Mozárabes, mudéjares, morisques, crypto-musulmans (XIeXVIIIe s.)», en B. BENNASSAR y R. SAUZET (eds.), Chrétiens et musulmans à la Renaissance, Paris, Honoré Champion Éditeur, 1997, pp. 151-162. 
«El Profeta del Islam, según el P. Traggia: una evolución católica de fines del siglo XVIII», Al-Andalus-Magreb. Homenaje al Profesor Braulio Justel Calabozo, 4, 1996, pp. 91-104.

«Sobre kanisa (iglesia), kanis (sinagoga) y kanisiyya (ruinas religiosas): toponimia y Arqueología», Qurțuba, 2, 1997, pp. 49-57.

«Morvedre islàmica i els cristians de fora i de dintre: Conquesta, Frontera i Mossàrabs», Braçal. Revista del Centre d'Estudis del Camp de Morvedre, 1718, 2, 1998, pp. 521-525.

«Influènces de la família musulmana sobre comportaments familiars de països mediterranis no musulmans», en M. ${ }^{a}$ A. Roque (ed.), Valors i diversitat cultural a les societats d'Europa i del Magreb, Barcelona, Institut Català de la Mediterrànea, 1998, pp. 232-248.

«'Sa Ràpita' de Campos, a Mallorca, topònim araboislàmic i document històric», en Josep MASSOT I MunTANER (ed.), Estudis de Llengua i Literatra en honor de Joan Veny, Montserrat, Publicacions de l'Abadia de Montserrat, 1998, vol. 2, pp. 663-689 [reed. en La Rábita en el Islam: estudios interdisciplinares, pp. 173-180].

«Mozarabs an Emblemátic Christian Minority in Islamic al-Andalus», en M. MARín (ed.), The Formation of al-Andalus, Ashgate, Aldershot, 1998, pp. 182-204.

«Bibliografía de mudéjares y moriscos», Sharq al-Andalus. Estudios Mudéjares y Moriscos, 14-15, 1997-1998, pp. 273-309. (Con Luis F. Bernabé Pons.)

«Nota sobre el concepto cultural euro-árabe de 'Mudéjar', según Guillermo Gustavino (1904-1977)», Sharq al-Andalus. Estudios Mudéjares y Moriscos, 14-15, 1997-1998, pp. 343-351.

«Los moriscos y sus descendientes después de la expulsión (después del cuadro del desembarco de Orán)», en José MiRANDA (ed.), La expulsión de los moriscos, Valencia, Fundación Bancaixa, 1998, pp. 41-70.

Jesús entre judios, cristianos y musulmanes hispanos (siglos VI-XVII), Granada, Universidad de Granada, 1999 [trad. alemana Jesus zwischen Juden, Christen und Muslimen. Interreligiöses Zusammenleben auf der Iberischen Halbinsel (6.-17), Jahhrhundert, Frankfurt, Otto Lembeck, 2002].

«Léxico y onomástica hispánicos de los moriscos conservados en Tunicia», VII Simposio Internacional de Mudejarismo. Teruel, 19-21 de septiembre de 1996, Teruel, Centro de Estudios Mudéjares, 1999, pp. 633-642. (Con Abdel-Hakim Gafsi.)

«'Ahd, Muslim/ Mudejar/Morisco Communities and Spanish Christian Authorities», en R.I. BuRNS y P. CHEVEDDEN, with a contribution by..., $\mathrm{Ne}$ gotiating cultures. Bilingual Surrender Treaties in Muslim Crusader-Spain under James the Conqueror, Leiden, E.J. Brill, 1999, pp. 195-212.

«El islam y algunos elementos de sus evoluciones en el siglo XXI», Anales de Historia Contemporánea. Universidad de Murcia, 16, 2000, pp. 107-117. 
«Elements cristians, islamics i jueus en l'adopcionisme de Feliu d'Urgell», en Josep PERARNAU (ed.), Jornades Internacionals sobre el Bisbe Feliu d'Urgell, La Seu de Urgell, 28-30 de setembre de 1999, Urgell, Facultat de Teología de Catalunya-Societat Urgel-liana, 2000, pp. 43-71.

«Los moriscos frente a la Inquisición, en su versión islámica del cristianismo», en Joaquín Pérez Villanueva y Bartolomé EsCANDEll (eds.), Historia de la Inquisición en España y en América. III. Temas y problemas, Madrid, BAC-Centro de Estudios Inquisitoriales, 2001, pp. 736-770 [reed. en Encuentros Islamo-cristianos, 2001].

L'Alcorà. Traducció de l'àrab al català, introducció a la lectura i cinc estudis alcorànics, per Míkel de Epalza, catedràtic d'Estudis Àrabs i Islàmics, amb la col·laboració de Joseph Forcadell i Joan M. Perujo, de la Universitat d'Alacant, Barcelona, Proa, 2001.

“ «Con traduir l'Alcorà per als qui no saben l'àrab?», L'Espill, 2a època, 8-9, 2001, pp. 136-146.

«Félix de Urgell: influencias islámicas encubiertas de judaísmo y los mozárabes del siglo VIII», Acta historica et archaeologica mediaevalia. Homenatge al Dr. Manuel Riu i Riu, vol. 2, 22, 2001, pp. 31-66.

«Moriscos contra Carlos V: Argel y el nuevo modelo de inserción de los musulmanes hispanos en el Magreb (1516-1541)», en José MARTínEZ MILLÁN (coord.), Carlos V y la quiebra del humanismo político en Europa (15301558), Madrid, Sociedad Estatal para la Conmemoración de los Centenarios de Carlos V y Felipe II, 2001, vol. I, pp. 447-468.

«Papel político de los moriscos en el nacimiento de la Argelia moderna en tiempos de Carlos V», en María Jesús Rubiera Mata (coord.), Carlos $V$, los moriscos y el Islam, Alicante, Sociedad Estatal para la Conmemoración de los Centenarios de Felipe II y Carlos V, 2001, pp. 201-231.

«Tres historiadores y políticos de Argelia presentan la política de Carlos V con la naciente Argelia moderna: Az-Zahhar (m. 1872), Zavala (1886) y Al-Madanî (m. 1983)», en María Jesús RubierA Mata (coord.), Carlos V, los moriscos y el Islam, Alicante, Sociedad Estatal para la Conmemoración de los Centenarios de Felipe II y Carlos V, 2001, pp. 233-267.

«Les structures d'accueil des exilés andalous et le cosmopolitisme islamique méditerranéen», en Dirāsāt fì-l-atār wa-n-naqā'iš wa-t-tārīj takrīman liSulaymān Muștafā Zbīss. Mélanges d'Archéologie, d'Épigraphie et d'Histoire offerts à Slimane Mustapha Zbiss, Tunis, Institut National du Patrimoine, 2001, pp. 83-98.

«Traduccions catalanes del Alcorà», en Joies escrites: Els fons bibliogràfics àrabs de Catalunya, Barcelona, Institut Català de la Mediterrània-Lunwerg Editores, 2002, pp. 101-113 [hay traducciones al castellano y al inglés del mismo año]. 
"Alguns antecedents cristians de la primera traducció completa de l'Alcorà al catalá (Barcelona 2001)», Randa. Homenatge a Miquel Batllori, I, 48, 2002, pp. 13-26.

"Testimonio de décadas de colaboración con el Profesor Harvey», Sharq alAndalus. Estudios Mudéjares y Moriscos, 16-17, 1999-2002, pp. 7-14.

«Sidi Bulgayz, protector de los moriscos exiliados en Túnez (s. XVII): Nuevos documentos traducidos y estudiados», Sharq al-Andalus. Estudios Mudéjares y Moriscos, 16-17, 1999-2002, pp. 145-178.

«Nota necrológica. Fallecimientop del historiador tunecino, descendiente de moriscos, Ilmo. Sr. Slimane-Mústafa Zbiss», Sharq al-Andalus. Estudios Mudéjares y Moriscos, 16-17, 1999-2002, pp. 375-378.

«El Corán de mañana y de siempre», Vanguardia dossiers. ¿Hacia dónde va el Islam?, 1, 2002, pp. 29-31.

«El Corán», Lateral: revista de cultura, 96, 2002, p. 29.

«Antecedentes islamocristianos concretos de la traducción del Corán al catalán», 'Ilu. Revista de ciencias de las religiones, 8, 2003, pp. 213-224.

«Algunos elementos constantes del urbanismo musulmán», en G. CRUZ ANDREOTTI y A. PÉREZ JimÉNEZ (coords.), De la aldea al burgo: la ciudad como estructura urbana y politica en el Mediterráneo, Madrid-Málaga, Ess. Clásicas, 2003, pp. 283-312.

"Els Moriscos o Andalusins en la historia viscuda pels tunisians», en VV.AA., Tunísia, terra de cultures, València, Museu de Prehistòria i de les Cultures de València-Institut Europeu de la Mediterrània, 2003, pp. 145-152.

«El Corán y sus traducciones: algunos problemas islamológicos y de traducción, con propuestas de soluciones», en María Àngels RoQuE (ed.), El islam plural, Barcelona, Bellaterra, 2003, pp. 379-400.

, «Versión literaria del Corán: una traducción en equipo», Hieronymus Complutensis: el mundo de la traducción, 11, 2004, pp. 7-24.

- Traducir del árabe, Madrid, Gedisa, 2004. (Dir., con María Jesús Rubiera.)

, «Especificidades religiosas de la lengua árabe y de sus traducciones», en Traducir del árabe, pp. 43-106.

«Imágenes entre ambos lados del Mediterráneo: geografía e historia, del atlas al icono», en Bernabé López GARCíA y Mohamed BERriAne (dirs.), Atlas de la inmigración marroquí en España 2004, Universidad Autónoma de Madrid-Observatorio Permanente de la Inmigración, 2004, pp. 19-21.

La Rábita en el Islam: estudios interdisciplinares. Congressos Internacionals de Sant Carles de la Ràpita (1989, 1997), Sant Carles de la Ràpita, Ajuntament de Sant Carles, 2004. (Coord., con Francisco Franco Sánchez.)

«Los estudios sobre las rábitas en la actualidad (1998)», en La Rábita en el Islam: estudios interdisciplinares, pp. 29-42. 
«Entrevista al sr. Zbiss y a su familia sobre los moriscos y sus descendientes en Tunisia», IX Simposio Internacional de Mudejarismo. Mudéjares y moriscos: cambios sociales y culturales, Teruel, Centro de Estudios Mudéjares, 2004, pp. 437-448. (Con Abdel-Hakim Gafsi-Slama.)

«Texto sobre la llegada del cónsul general Francisco Seguí a la Regencia de Túnez (1804) y su correspondencia diplomática», Awrâq, 22, 2001-2005, pp. 171-182. (Con Abdel-Hakim Gafsi Slama.)

«L'Alcorà en català: traducció literaria d'un text sagrat», Quaderns. Revista de Traducció, 12, 2005, pp. 227-244. (Con Josep Vicent Forcadell Saport y Joan M. Perujo Melgar).

«Breve estudio sobre el embajador Alfonso de la Serna: escritor y promotor de estudios hispano-árabes en el Mágrib (Túnez y Marruecos, moriscos y el Estrecho)», Awrâq, 23, 2006, pp. 201-217.

, «Nota en homenaje a la 9a edición de El Corán de Julio Cortés (2005)», Boletín de la Asociación Española de Orientalistas, 42, 2006, pp. 85-97.

"Guerras y paces hispano-turcas. Algunas repercusiones teológicas en la obra de Manuel Traggia (fines del siglo XVIII)», Anuario de Historia de la Iglesia, XVI, 2007, pp. 217-228.

«Relaciones entre España y Túnez en el siglo XIX: Nueva documentación y síntesis», Anales de Historia Contemporánea. Universidad de Murcia. Monográfico: Las relaciones de España con el Magreb. Siglos XIX-XX, 23, 2007, pp. 259-276. (Con Abdel-Hakim Slama-Gafsi.)

«Note about the Muslim Conquest of the 7th.-8th. Centuries: the Basque, Berber, Norse Viking, Norman and Briton 'Magicians'», Imago temporis. Medium Aevum, 1, 2007, pp. 61-69.

"Nota sobre un nuevo "falso" en árabe, de moriscos en el exilio, antes de la expulsión general (¿Túnez, 1603?): la pseudo-Tuhfa de Turmeda (3a parte)», Sharq Al-Andalus. Estudios Mudéjares y Moriscos, 18, 2003-2007, pp. 133-144.

«El embajador Alfonso de la Serna, escritor y promotor de estudios sobre los moriscos en el Magreb», Sharq Al-Andalus. Estudios Mudéjares y Moriscos, 18, 2003-2007, pp. 215-252.

«Vascos y árabes, en el siglo VIII y en el XIX. Historia e historias», Hesperia. Culturas del Mediterráneo, 6, 2007, pp. 123-153. (Con Joaquín del Valle de Lersundi.)

«Estudios sobre los mudéjares y moriscos (los 'andalusíes') exiliados de España y sus descendientes 'allende' (publicados en Teruel y en Túnez, 1975-2005)», X Simposio Internacional de Mudejarismo: memoria y futuro [1975-2005], Teruel, Centro de Estudios Mudéjares, 2007, pp. 341-366. (Con Abdel-Hakim Gafsi Slama.) 
«La obra del Emir 'Abd Allah de Granada (siglo XI) como alegato político en un proceso judicial)», Hesperia. Culturas del Mediterráneo, 8, 2008, pp. 151-156. (Con Ricardo Lardizábal.)

"Los mayûs ("magos"): un hápax coránico (Q XII, 17), entre lo étnico y lo jurídico, hasta su acepción en Al-Ándalus», en Miguel HeRnANDO DE LARRAMENDi y Salvador PeÑa MARTín (eds.), El Corán ayer y hoy. Perspectivas actuales sobre el Islam. Estudios en honor del Profesor Julio Cortés, Córdoba, Berenice, 2008, pp. 399-414.

El Corán y sus traducciones: propuestas, Alicante, Universidad de Alicante, 2009. (Con Josep Vicent Forcadell Saport y Joan M. Perujo Melgar.)

El español hablado en Túnez por los moriscos o andalusies y sus descendientes (siglos XVII-XVIII). Material léxico y onomástico documentado, siglos XVII-XXI), València, Universitat de València-Universidad de Granada-Universidad de Zaragoza, 2010. (Con Abdel Hakim Slama Gafsi.) 